\title{
Community structure in mediterranean shallow lentic ecosystems: size-based vs. taxon-based approaches
}

\author{
X. D. Quintana, D. Boix, A. Badosa, S. Brucet, J. Compte, S. Gascón, R. López-Flores, \\ J. Sala, \& R. Moreno-Amich \\ Institut d'Ecologia Aquàtica. Universitat de Girona. Campus Montilivi 17071. Girona. Spain. \\ Corresponding author: xavier.quintana@udg.es
}

\begin{abstract}
The main environmental variables determining the community structure and the functioning of Mediterranean shallow lentic ecosystems are described. These ecosystems are characterized by the unpredictability of their water inputs and the high variability in their water level and physical and chemical composition. Variations in flooding, salinity, and water turnover are determinant in species composition and nutrient dynamics. Taxon-based and size-based approaches to the study of the community structure of aquatic organisms that colonise these ecosystems are also compared. The conventional taxonomic approach, based on the determination of species composition, has been used for the identification of patterns in species richness, distribution and temporal dynamics, and for ecological requirements of species and their potential use as ecological indicators. This taxonbased approach has been compared with a size-based approach, where individuals are classified by their size. Size-based approach gives complementary information about community structure and dynamics, especially when communities are dominated by a single species. The use of size diversity combined with species diversity is suggested for a more complete understanding of community structuring in this type of ecosystem. Detailed examples of two Mediterranean shallow lentic ecosystems, the salt marshes of the Empordà wetlands and the Espolla temporary karstic pond, which differ in hydrology and water origin, are used to discuss the suitability of these different approaches.
\end{abstract}

Keywords: Mediterranean wetlands, shallow lakes, size diversity, species diversity, biomass size spectra.

\section{RESUMEN}

Los ecosistemas leniticos someros mediterráneos se caracterizan por la impredictibilidad en las entradas de agua y por la elevada variabilidad en el nivel del agua y su composición fisica y química. Se describen aquí las principales variables ambientales que determinan la estructura de la comunidad y el funcionamiento de estos ecosistemas. Variaciones en la inundación, la salinidad y la tasa de renovación del agua son determinantes en la composición de especies y en la dinámica de nutrientes. Se comparan también aproximaciones al estudio de la comunidad basadas en la composición taxonómica con las basadas en la distribución de tamaños. La aproximación taxonómica convencional, basada en la determinación de la composición de especies, es adecuada para la identificación de patrones en la distribución y en la dinámica temporal de la especies, así como para el análisis de los requerimientos ambientales de las diferentes especies y su uso potencial como indicadores ecológicos. Esta aproximación taxonómica se ha comparado con otra aproximación basada en el tamaño corporal, donde los individuos se clasifican por su tamaño. La aproximación basada en el tamaño proporciona información complementaria de la estructura y dinámica de las comunidades, especialmente cuando en estas comunidades hay una especie dominante. Se sugiere el uso combinado de una diversidad de tamaños y una diversidad de especies para una comprensión más completa de la estructuración de las comunidades en este tipo de ecosistemas. Para discutir si estas diferentes aproximaciones son o no adecuadas, se presentan datos de dos ecosistemas mediterráneos leníticos y someros: las marismas de Aiguamolls de l'Empordà y la laguna de Espolla, una surgencia cárstica de inundación temporal.

Palabras clave: Humedales mediterráneos, lagos someros, diversidad de tamaños, diversidad de especies, espectros de biomasa.

\section{INTRODUCTION}

Mediterranean shallow lentic ecosystems include shallow lakes, wetlands, coastal marshes and ponds, which present a hydrology strongly con- ditioned by the Mediterranean climate. Irregularity and unpredictability of water inputs and flooding periods have a strong influence on their hydrology, causing not only sharp water level fluctuations but also wide fluctuations in 
their physical, chemical, and biological composition (Fernández-Aláez, et al., 1999; Beklioglu et al., 2003; Romo et al., 2004; Alvarez-Cobelas et al., 2005). Spatial and temporal variability in water composition favours large environmental gradients over short time and spatial scales. As a consequence, species richness is very high, although this is frequently not well known and often neglected (Boix et al., 2001b; Boix \& Sala 2002; Martinoy et al., in press).

Most of these ecosystems are characterized by sudden inputs of water, coinciding with flooding events, which are frequently followed by long periods of confinement. Decreases in water levels during confinement may lead to desiccation or, at least, to very low levels. Therefore, these ecosystems may become temporary and suffer one or two dry periods throughout the year. This characteristic hydrology strongly determines the ecological functioning of these ecosystems, where the duration of the hydroperiod and water turnover rate have been determined to affect water composition, nutrient dynamics, contaminant contents and aquatic community structure (Quintana et al., 1998a and 1998b; López-Flores et al., 2003; Boix et al., 2004). This sudden flooding - confinement hydrology is less determinant for the nutrient cycle in those Mediterranean salt marshes or coastal lagoons where other factors such as human regulation, riverine inputs or a permanent connexion with the sea are more relevant (Heurteaux et al., 1992; Comín \& Valiela, 1993; Frascari et al., 2002; Pérez-Ruzafa et al., 2002; Villena \& Romo, 2003).

Temporary habitats have no fish unless they are filled with water coming from permanently flooded ecosystems. In the absence of fish, invertebrate predation and competitive interactions among invertebrates become more relevant in the trophic structure of the aquatic community (Wellborn et al., 1996). Situations in which a single invertebrate species dominates are frequent in Mediterranean shallow water bodies (Quintana et al., 1998b; Brucet et al., 2005b) due to competitive exclusion. When the invertebrate community is dominated by one single species, intraspecific competitive interactions will take place and the separation of niches among diffe-

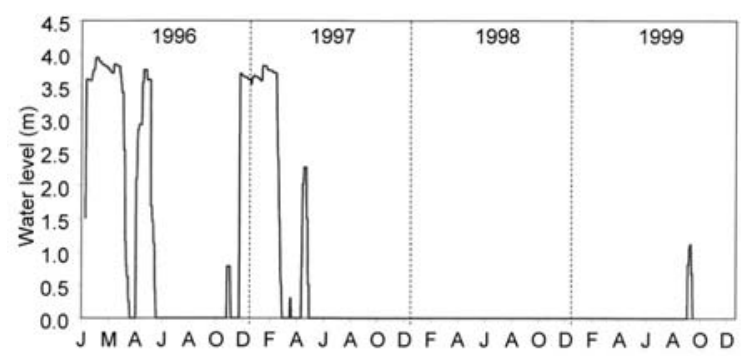

Figure 1. Water level over 7 consecutive hydroperiods at the Espolla pond (1996-1999). Nivel del agua a lo largo de 7 hidroperíodos consecutivos en la laguna de Espolla (19961999).

rent stages may allow the dominant species to reduce intraspecific competition (Werner \& Gilliam 1984). In this case, a size-based approach of the study of the community structure would probably show the niche partitioning better than the traditional taxon-based approach.

In this paper the main physical and chemical characteristics of several shallow lentic water bodies located in Catalonia (NE Spain) are described, and studies of the composition and size distribution of their species are compared. We mainly discuss data from two ecosystems with different hydrology and water origin: the salt marshes of the Empordà wetlands (Alt Empordà and Baix Ter wetlands) and the temporary karstic pond of Espolla. The former are mainly flooded by sudden seawater inputs during sea storms, whilst the latter is flooded by karstic groundwater springs. Our aim is to show the main limnological characteristics of these shallow lentic ecosystems, and to compare the conclusions obtained in the study of the community structure by means of two different approaches, the taxon-based and the size-based approaches.

\section{HYDROLOGY AND NUTRIENT DYNAMICS}

Hydroperiods in the karstic Espolla pond (Fig. 1) are characterized by rapid flooding and drying and by a high water turnover rate throughout the hydroperiod (Boix et al., 2004). Conductivity values do not increase significantly during the drying out period, indicating no substantial 


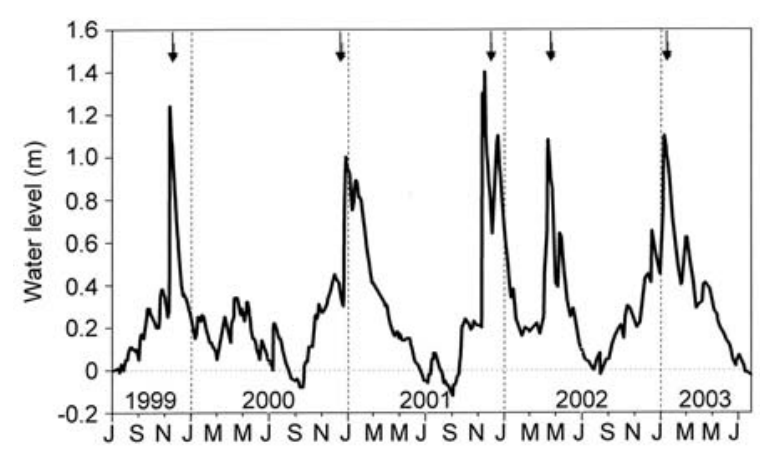

Figure 2. Variation in the water level ( $\mathrm{m}$ above the average sea level) in Fra Ramon lagoon (Baix Ter wetlands) during four hydrological cycles (from 1999 to 2003, separated by dotted lines). Arrows indicates sea storm events. The zero water level corresponds to the average sea level over the last 15 years. Variación del nivel del agua (cota en $m$ sobre el nivel medio del mar) en la laguna Fra Ramon ("Aiguamolls del Baix Ter") durante cuatro ciclos hidrológicos (desde 1999 a 2003, separados por lineas discontinuas). Las flechas indican temporales de mar. El nivel cero corresponde al nivel medio del mar en la zona durante los últimos 15 años.

changes in water ionic composition. The water is poor in nutrients, especially in phosphorus, due to its subterranean origin. High water turnover during flooding and a relatively short drying period lead to fast changes in nutrient composition only at the end of the hydroperiod.

The hydrology in the Empordà salt marshes is determined by sudden flooding, mostly caused by marine intrusions during sea storms, when waves cross the sand bar. At least one sea storm occurs every year, but in some unusual years (e.g. during the 2001-2002 cycle) several sea storms have been registered. Although sea storms are more frequent between autumn and spring, their appearance is very irregular and no seasonal pattern can be observed (Fig. 2). Flooding periods are followed by long periods of confinement, when the water level gradually decreases and salinity increases due to evaporation (Quintana, 2002b; Quintana et al., 2004; Badosa et al., in press). Neither the Espolla pond nor the Empordà salt marshes have any regular seasonal pattern in hydrology and ecological processes.

Nutrient dynamics is strongly affected by this sudden flooding-long confinement hydrology in the Empordà salt marshes. Nitrate content increases during flooding periods, whilst confinement favours the accumulation of phosphorus and the loss of the inorganic forms of nitrogen, most likely caused by denitrification (Badosa et al., in press). The simultaneous accumulation of phosphorus and loss of nitrogen lead to especially low $\mathrm{N} / \mathrm{P}$ ratios, which is called differential confinement of nutrients (Quintana et al., 1998a). Water turnover and differential confinement also affects the accumulation of other compounds. Thus, some persistent pesticides and heavy metals tend to concentrate in some lagoons during confinement, whilst some more degradable pesticides appear only when the water turnover rate is high due to runoff (López-Flores et al., 2003; Salvadó et al., in press).

Moreover, a study of salinity and nutrient composition and their variations throughout the year carried out in several water bodies located in the area of the Empordà wetlands, reveals five types of shallow water ecosystems (Trobajo et al., 2002): 1) hyperhaline wetlands, 2) brackish wetlands, 3) hypereutrophic freshwater wetlands; 4) meso-eutrophic freshwater wetlands; and 5) freshwater springs. Martinoy et al., (in press) added more water body types, such as rice fields, estuarine lotic habitats, and ephemeral wetlands (Table 1). Salinity, water permanence, and nutrient composition appear to be the main environmental factors determining wetland classification and the shift between alternative stable states of macrophyte-periphyton-phytoplankton predominance. This is a common feature of most Mediterranean wetlands and shallow lakes (Britton \& Podlejski, 1981; Alonso, 1998; Romo et al., 2005; Fernández-Aláez et al., 2004).

\section{COMMUNITY STRUCTURE OF AQUATIC ORGANISMS: TAXON-BASED APPROACHES}

Classification of shallow lakes according to physical and chemical characteristics may be verified by their faunal composition. A study developed in Catalonia, within the framework of the implementation of the Water Framework 
Table 1. Physical, chemical and biological characteristics of each water body type of the Empordà wetlands. Mean values in bold and coefficients of variation (\%) in italics. Legend: HHW: hyperhaline wetlands; BW: brackish wetlands; HTW: hypereutrophic freshwater wetlands; MFW: meso-eutrophic freshwater wetlands; FS: freshwater springs; LW: lotic waters; EBW: ephemeral brackish wetlands; EFW: ephemeral freshwater wetlands; RF: rice fields; - : no data available. Características fisicas, químicas y biológicas de las diferentes tipologías de masas de agua de los humedales del Empordà. Valores medios en negrita y coeficientes de variación (\%) en cursiva. Leyenda: HHW: humedales hiperhalinos; BW: humedales salobres; HTW: humedales hipertróficos de agua dulce; MFW: humedales meso-eutróficos de agua dulce; FS: surgencias; LW: sistemas lóticos; EBW: humedales salobres efimeros; EFW: humedales de agua dulce efimeros; RF: arrozales; —: datos no disponibles.

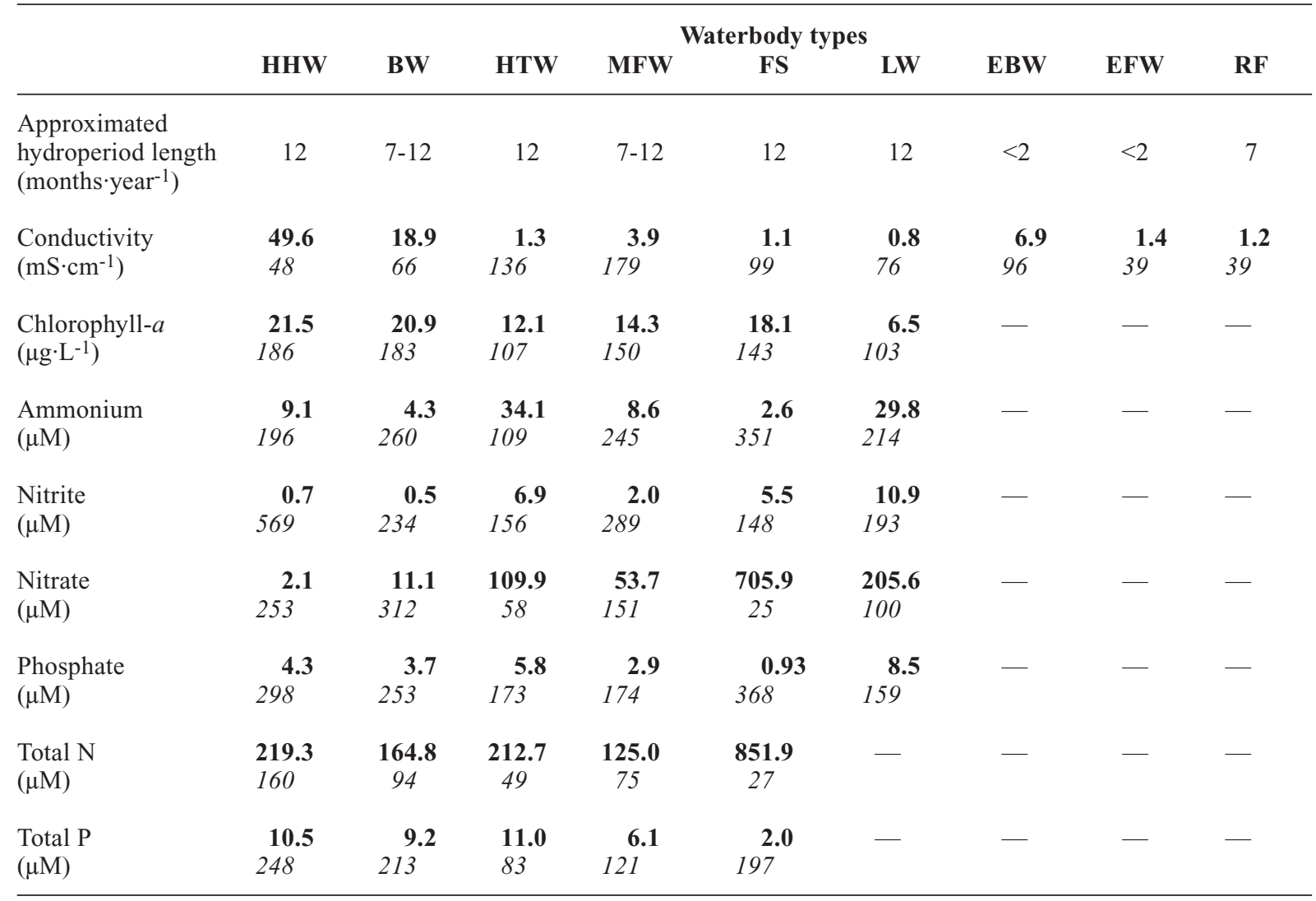

Directive and using CA multivariate analysis of invertebrate species composition, revealed four types of shallow lentic ecosystems, each one with a characteristic faunal composition (Boix et al., 2005): 1) permanent (or semi-permanent) freshwater wetlands, including fresh or oligohaline waters (conductivity $<5 \mathrm{mS} \cdot \mathrm{cm}^{-1}$ ); 2) temporary freshwater wetlands, with the same conductivities, which dry out every year; 3 ) thalassohaline wetlands, including temporary and permanent wetlands with average conductivities higher than $5 \mathrm{mS} \cdot \mathrm{cm}^{-1}$ and marine influence; and 4) athalassohaline wetlands, with conductivities higher than $5 \mathrm{mS} \cdot \mathrm{cm}^{-1}$, not caused by marine intrusion, but by the endorheic concentration of salts (Fig. 3). The salt marshes of the Empordà wetlands belong to thalassohaline ecosystem type, whilst the Espolla pond is an example of freshwater temporary ecosystem. It is worth pointing out that temporary and permanent thalassohaline water bodies have a similar faunal composition, but different community structures (Brucet et al., 2005b; Gascón et al., 2005).

Successional patterns of aquatic invertebrates are related to hydrology. Although some changes are associated with seasonality, no regular seasonal pattern is observable in aquatic invertebrate dynamics, and changes in species composition are irregular throughout the year, as a consequence of the irregular hydrology (Quintana et al., 1998b; Boix et al., 2001a). In the Empordà salt marshes, several situations or phases have 


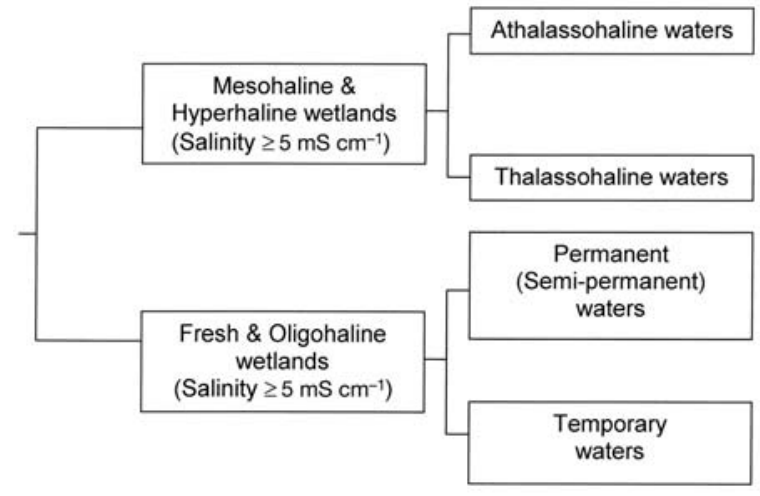

Figure 3. Dichotomic diagram that identifies the main wetland types of Catalonia, modified from Boix et al. (2005). Diagrama dicotómico que identifica los principales tipos de humedales de Catalunya, modificado de Boix et al. (2005).

been identified in the zooplankton temporal pattern (Fig. 4), each one dominated by a characteristic species (Quintana et al., 1998b; Brucet et al., 2005b; Badosa et al., in press): The rotifer Synchaeta spp. dominates at the beginning of the cycle just after an intense input of water, and is replaced soon after by copepod populations, for- med by the cyclopoid Diacyclops bicuspidatus odessanus and nauplii of the calanoid Eurytemora velox. Later, when the water level decreases, late stages of $E$. velox may reach close to $100 \%$ of the zooplankton total biomass. In spring the population of E. velox is substituted by another calanoid, Calanipeda aquaedulcis. During drought periods, benthic species such as the harpacticoid Cletocamptus confluens or the amphipod Gammarus aequicauda colonize the water column. Species composition during drought periods may differ depending on the degree of eutrophy. Under oligotrophic conditions, with high salinity and low N/P ratios, dense populations of the medusa Odessia maeotica and polychaete larvae (Polydora sp.) may appear. On the other hand, a drastic reduction of the water level in high eutrophic waters frequently causes incidents of hypereutrophy, where oxygen oversaturations during midday alternate with nocturnal anoxias. The rotifer Brachionus plicatilis and several species of ciliates dominate in these hypereutrophic situations.

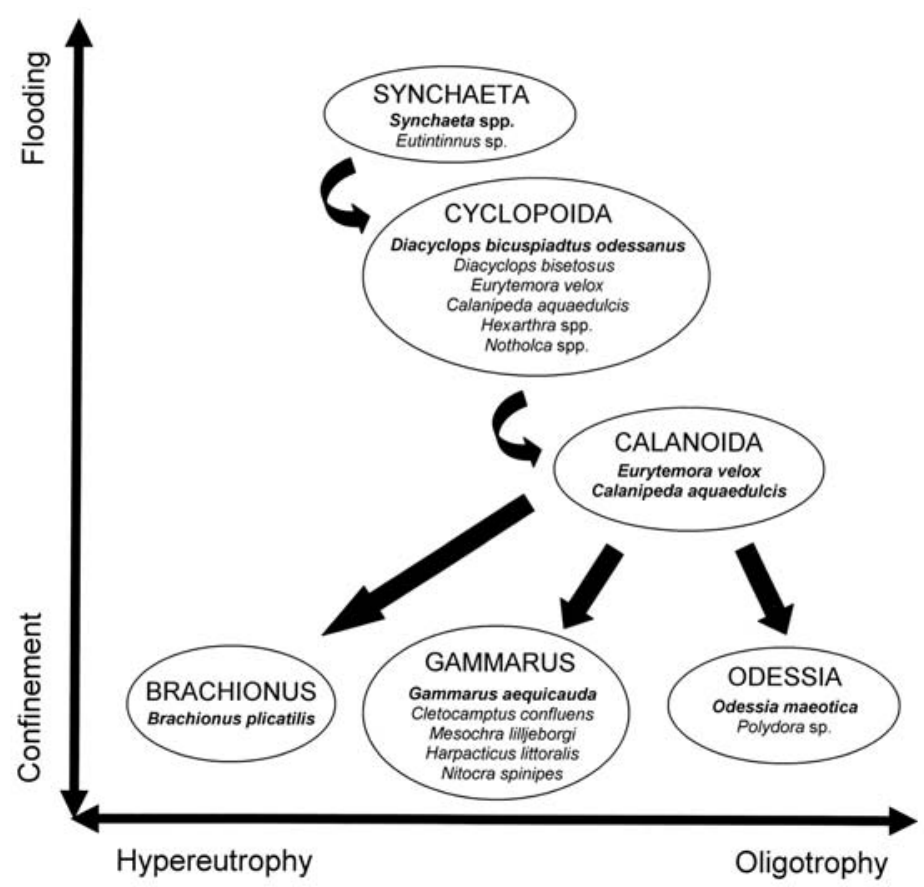

Figure 4. Conceptual model of plankton succession in the salt marshes of the Empordà wetlands, adapted from Quintana et al. (1998b), Brucet et al. (2005c) and Badosa et al. (2006). Each group corresponds to different situations of the succession, characteristic taxa are shown, dominant taxa in bold. Modelo conceptual de sucesión planctónica en la marisma de los "Aiguamolls de l'Empordà", adaptado de Quintana et al. (1998b), Brucet et al. (2005b) y Badosa et al. (2006). Cada grupo corresponde a diferentes situaciones de la sucesión, se muestran los taxones característicos, y en negrita los dominantes. 
Similarly, heleoplankton succession in the temporary karstic pond of Espolla is related to the changes in the water turnover rate. Thus, just after flooding, when the water turnover is maximal, the ostracods Heterocypris incongruens and Eucypris virens are the dominant species of heleoplankton. If the high water turnover rate is maintained for approximately three weeks, the dominant species are substituted by the copepod Megacyclops viridis and the cladoceran Simocephalus vetulus. Finally, when the water turnover rate is minimal (at the end of the hydroperiod), the more abundant species are the cladocerans Daphnia pulicaria and Moina brachiata (only in spring hydroperiods), and the copepod Cyclops sp.

Changes in hydrology also determine the physical and chemical composition of sediment and, hence, the spatial distribution of benthic species composition in the Empordà salt marshes: 1) non-disturbed permanent waters are characterized by a high density of individuals, total biomass and diversity; 2) non-disturbed temporary waters have lower richness and diversity values with little temporal variability; 3) disturbed temporary waters present a high taxonomic singularity and a high temporal variability of species richness and diversity (Gascón et al., 2005). Moreover, changes in hydrology have different effects on planktonic and benthic communities, the former responding to temporal changes due to hydrological disturbances (Quintana, 2002) and the latter being more related to spatial patchiness in water permanence (Gascón et al., 2005).

\section{Species' ecological requirements}

The wide range of physical and chemical characteristics found in the different water bodies of the Empordà wetlands, as well as the existence of spatial and temporal gradients, allows for the ecological preferences of the different species found therein to be analysed, thus contributing to the knowledge of their autoecology. Similar patterns are found in organisms with very different characteristics, such as ostracods and periphytic diatoms (Gifre et al., 2002; Trobajo et al., 2004a). In both cases, the range of variation of water characteristics where the different species are captured is very high for most species, especially for those species found in salt marshes. This seems to be common in other aquatic organisms that colonize these fluctuant environments (Boronat et al., 2001). Fish such as Aphanius iberus tolerate wide ranges in salinity variations (Fernández-Delgado et al., 1988; Vargas \& Sostoa, 1997; Oltra \& Todolí, 2000) and macrophytes such as Ruppia cirrhosa adapt their reproductive patterns to changes in water level (Gesti et al., 2005). Some diatoms may also change their shape as a response to changing environmental conditions (Trobajo et al., 2004b). Salinity, water turnover, water permanence, and productivity are described as the main factors determining species distribution in these ecosystems. In the case of the Empordà wetlands, the aquatic systems under salinity or trophic constraint (hyperhaline and hypereutrophic water bodies) are characterized by low values of species richness per visit and singularity, and by a higher proportion of species of crustaceans than of insects (Table 2).

Moreover, the interannual variability of these environmental factors is high in Mediterranean aquatic systems (Álvarez-Cobelas et al., 2005; Britton \& Crivelli, 1993). For example, hydroperiod length may vary considerably among years causing drastic interannual changes in the population abundance of some species that do not tolerate desiccation, such as the amphipod Corophium orientale (Gascón et al., in press). Even population dynamics and reproduction of species that exclusively live in temporary waters are highly dependent on the flooding duration. This is the case of Triops cancriformis in the Espolla pond (Boix et al., 2002).

\section{Biological indicators}

The knowledge of species composition and its relation with trophic state variables, allow its use as an ecological indicator. To this effect, new tools for the assessment of ecological status have been successfully developed at a regional scale in Catalonia as required by the European Water Framework Directive (Directive 2000/60/EC). This includes the use of 
Table 2. Species richness per visit, of crustaceans and insects for each water body type of the Empordà wetlands. Singularity, cumulative species richness, and crustaceans-insects ratio are also showed. Singularity was measured as the proportion of the number of species found only in one water body type in relation with total number of species of this water body type. Legend: HHW: hyperhaline wetlands; BW: brackish wetlands; HTW: hypertrophic freshwater wetlands; MFW: meso-eutrophic freshwater wetlands; FS: freshwater springs; LW: lotic waters. Riqueza de especies por visita de crustáceos e insectos en cada tipología de masa de agua de los humedales del Empordà. También se muestra la singularidad, la riqueza acumulada de especies y la relación entre crustáceos e insectos. La singularidad se ha calculado como la proporción del número de especies encontradas únicamente en una tipología de masa de agua en relación con el número total de especies para esa tipología de masa de agua. Leyenda: HHW: humedales hiperhalinos; BW: humedales salobres; HTW: humedales hipertróficos de agua dulce; MFW: humedales meso-eutróficos de agua dulce; FS: surgencias; LW: sistemas lóticos.

\begin{tabular}{|c|c|c|c|c|c|c|}
\hline & \multicolumn{6}{|c|}{ Waterbody types } \\
\hline & HHW & BW & HTW & MFW & FS & LW \\
\hline \multicolumn{7}{|l|}{ Species richness per visit } \\
\hline Mean & 5 & 8 & 6 & 8 & 10 & 7 \\
\hline Maximum & 10 & 18 & 11 & 19 & 19 & 19 \\
\hline Minimum & 1 & 1 & 3 & 1 & 3 & 2 \\
\hline Cumulative species richness & 53 & 109 & 72 & 171 & 70 & 128 \\
\hline Crustacea & 35 & 62 & 48 & 76 & 24 & 47 \\
\hline Insecta & 18 & 47 & 24 & 95 & 47 & 81 \\
\hline Singularity & 0.04 & 0.19 & 0.04 & 0.20 & 0.13 & 0.29 \\
\hline Within Crustacea & 0.00 & 0.21 & 0.06 & 0.11 & 0.04 & 0.06 \\
\hline Within Insecta & 0.11 & 0.35 & 0.09 & 0.34 & 0.17 & 0.51 \\
\hline \multicolumn{7}{|l|}{ Ratio } \\
\hline Crustacea/Insecta & 1.9 & 1.3 & 2.0 & 0.8 & 0.5 & 0.6 \\
\hline
\end{tabular}

aquatic crustaceans and insects as water quality indicators (Boix et al., 2005) and the rapid assessment of the conservation status in terms of morphology, human use, water characteristics, and wetland vegetation (Sala et al., 2004).

Species composition may also show other ecological aspects not related to water quality. Short term changes in zooplankton species composition have been used as a measure of disturbance intensity in the Empordà salt marshes, indicating a strong dependence of the zooplankton community structure on hydrological changes (Quintana, 2002a). This relationship between community structure and disturbance intensity allows the testing of Connell's (1978) intermediate disturbance hypothesis, which postulates that maximum diversities are found at intermediate disturbances. Considering the results obtained in the Empordà salt marshes, this hypothesis may be reformulated as follows: at intermediate severity, the maximum links between species are found (Quintana, 2002a). The influence of hydrological disturbances to species composition in the Empordà salt marshes is not only restricted to planktonic communities. The Maturity index (MI) developed by Bongers (1990), applied to assess the disturbance effects on meiobenthic nematode assemblages, indicates that hydrological disturbances are also the main cause of variation in benthic communities (Gascón et al., in press).

\section{SIZE BASED APPROACHES}

During the last decades several authors emphasized the importance of body size as a community-organising unit in marine and freshwater ecosystems (Platt \& Denman, 1977; Strayer, 1991; Rodríguez, 1994; Kerr \& Dickie, 2001). It is based on the allometric relationship between body size and variables describing the main ecological processes, such as respiration, production, growth rate, and ingestion rate. The 
representation (on a logarithmic scale) of abundance as a function of the size of individuals, what is called the biomass-size spectrum, gives rise to a straight line with a slope close to -1 . Such a slope is achieved in many different environments, such as pelagic marine ecosystems, lakes, or shallow fluctuating ecosystems (Rodríguez \& Mullin, 1986; Gaedke 1992; Gilabert, 2001; Quintana et al., 2002). Besides the ecological relevance of this regularity, these authors also emphasized the interest in studying irregularities of the size-spectrum, rather than its regularity, for a more dynamic interpretation of the changes in size distribution relating to changes in environmental conditions.

Several reasons reveal the interest in studying the community structure using a size-based approach in aquatic communities of shallow lentic water bodies:

1. The different developmental stages of a single species may have different trophic roles. Changes in diet between stages are known for many copepods (Paffenhöfer, 1971, Poulet, 1977; Fernández, 1979). Differences in diet are found in the most abundant calanoids of the Empordà salt marshes (Compte unpublished data), and changes in amino acid composition during ontogeny, which may be related to changes in the diet (Guisande et al., 2003), have been described for these species (Brucet et al., 2005a).

2. Individuals of different species but of the same size may feed on the same preys, thus occupying the same trophic niche. Zooplankters found in the Empordà salt marshes (Quintana et al., 1998b; Brucet et al., 2005b, Badosa et al., 2006) often belong to species with a relatively similar feeding ecology.

3. Dominances of a single species of zooplankter are very frequent in shallow lentic ecosystems, like the Empordà salt marshes (Quintana et al., 1998b and 2004; Brucet et al., 2005b). Under conditions of dominance, intraspecific competition acquires more relevance, favouring trophic niche partitioning among different stages of the same species.

\section{The biomass-size spectrum}

Studies on biomass-size spectrum consist in the representation of abundance (either the number of individuals or biomass) as a function of body size (Rodríguez, 1994). This size distribution may be adjusted to a linear or non-linear model. Thereafter, changes in the model parameters, such as the fit $\left(\mathrm{r}^{2}\right)$ or the slope are described as having ecological meaning. The biomass-size spectrum most commonly used is the normalised biomass-size spectrum, where abundance is represented as a function of the size of the individuals, classified in size classes of regular amplitude. The inconvenience of this procedure is that it produces a discrete model, which is dependent on the choice of the size scale and the interval amplitude (Han \& Straskraba 1998). Vidondo et al. (1997) proposed the use of the underlying Pareto distribution, which is a probability density function and has the advantage of being a continuous function, where individuals should not be classified in size classes. The Pareto distribution has a cumulative distribution of probability defined as,

$$
\operatorname{prob}(\mathrm{s} \geqslant \mathrm{S})=\mathrm{K}^{\mathrm{c}} \mathrm{s}^{-\mathrm{c}}
$$

where $\operatorname{prob}(s \geqslant S)$ is the probability that a size (s) of an individual taken at random will be greater than a threshold size $\mathrm{S}$, expressed as a function of $s$. In practice, the term $\operatorname{prob}(\mathrm{s} \geqslant \mathrm{S})$ is calculated for each individual as the fraction of all individuals larger than or equal to itself $\left(\mathrm{N}_{\mathrm{s} \geqslant \mathrm{S}} / \mathrm{N}_{\mathrm{t}}\right)$. This model is linear at the logarithmic scale. Furthermore, the same authors define a more generalized non linear model, the Pareto type II model, which differs from the original Pareto model by the additive constant D,

$$
\operatorname{prob}(\mathrm{s} \geqslant \mathrm{S})=(\mathrm{K}+\mathrm{D})^{\mathrm{c}}(\mathrm{s}+\mathrm{D})^{-\mathrm{c}}
$$

The ordinary Pareto or Pareto type I is a special case of the second type when $\mathrm{D}=0$.

Several scalings in biomass-size spectra were described (Dickie et al. 1987). The primary or physiological scaling includes the size spectrum of all aquatic organisms (from bacteria to fish). 
The secondary or ecological scaling identifies regular sub distributions of the biomass-size spectrum for the whole community, covering well-defined size ranges, which generally correspond to ecological functional groups. A tertiary or population scaling is also identifiable when the spectrum shows a step pattern on the ecological scaling, generally associated with scant overlap in population size ranges.

Studies on biomass-size spectrum at the primary or physiological scaling in the Empordà salt marshes show that size distribution mainly depends on hydrology. Hydrological disturbances cause a decrease in the fit $\left(\mathrm{r}^{2}\right)$ of the biomass-size spectrum, and an increase in the slope. The slope also changes depending on the degree of eutrophy (Quintana et al., 2002). When only one functional group is considered (secondary or ecological scaling), for example the zooplankton community, three different types of size distribution are shown (Fig. 5) depending on environmental conditions (Brucet et al., 2005c). During
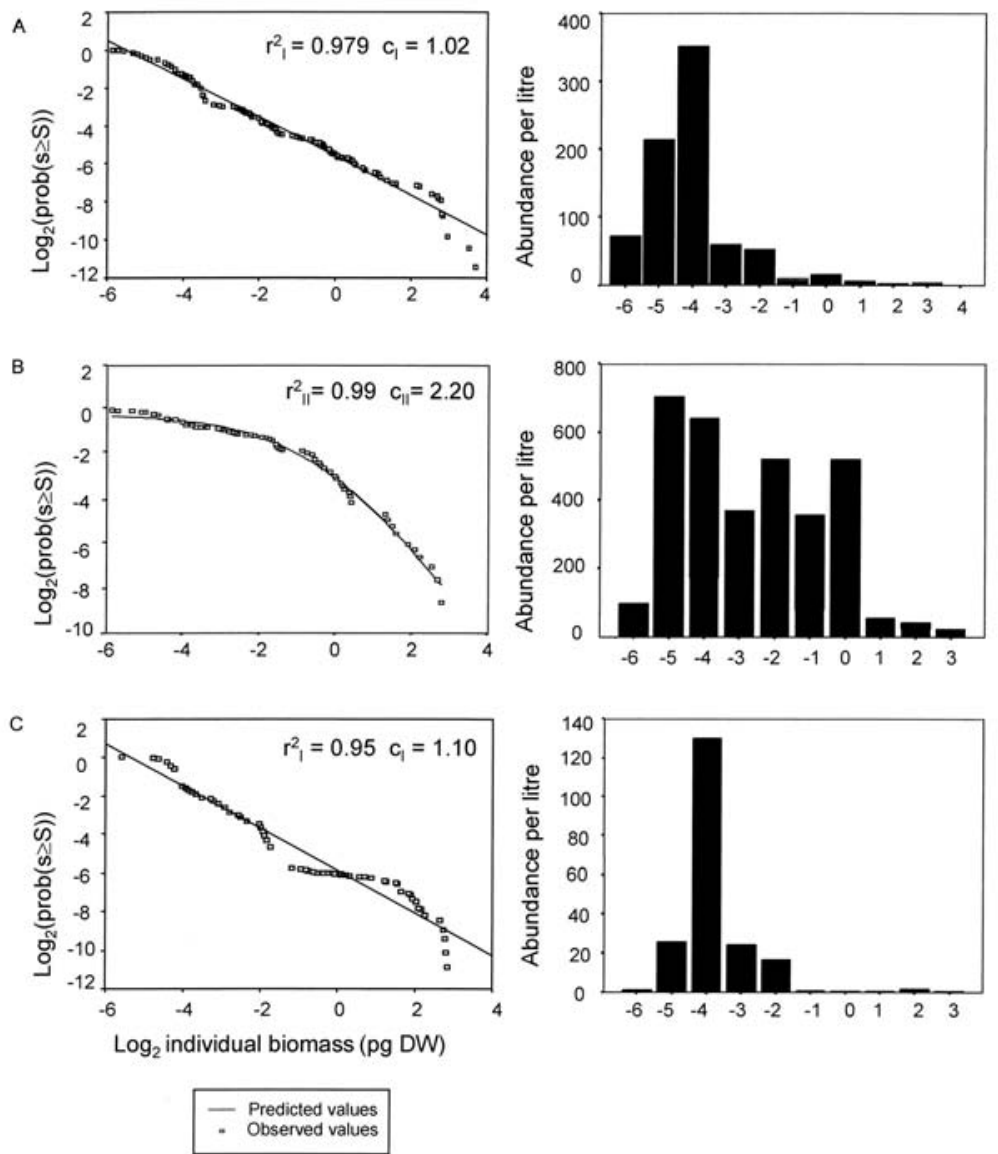

Figure 5. Types of biomass size spectra found in zooplankton samples and their fit to the Pareto model (left hand); $\mathrm{r}^{2}{ }_{\mathrm{I}}$ and $\mathrm{r}^{2}{ }_{\mathrm{II}}$ are the fit to the Pareto type I and the Pareto type II, respectively; $\mathrm{c}_{\mathrm{I}}$ and $\mathrm{c}_{\mathrm{II}}$ are the constant $\mathrm{c}$ of the Pareto type I and the Pareto type II models, respectively. (A) Linear spectrum, with better fit to linear model (Pareto type I); (B) curved spectrum, with better fit to non-linear model (Pareto type II); (C) example of step-like substructures. On the right, the graph that shows individuals abundance of each size class. All spectra are from a coastal lagoon in the Alt Empordà wetlands, modified from Brucet et al. (2005c). Tipos de espectros de biomasa encontrados en muestras de zooplancton y su ajuste al modelo de Pareto (izquierda); $r^{2}$ y $r^{2}{ }_{I I}$ son el ajuste al modelo de Pareto tipo Iy de Pareto tipo II, respectivamente; $c_{I} y c_{I I}$ son la constante c del modelo de Pareto tipo I y tipo II, respectivamente. (A) Espectro linear, con un mejor ajuste al modelo lineal de Pareto (Pareto tipo I), (B) espectro curvado, con un mejor ajuste al modelo no lineal (Pareto tipo II), (C) ejemplo de subestructuras escalonadas. A la derecha el gráfico correspondiente que muestra la abundancia de individuos por clase de tamaño. Todos los espectros son de una laguna costera de los "Aiguamolls del Alt Empordà", modificado de Brucet et al. (2005c). 
flooding conditions, and when competitive interactions are weak, size spectra are linear shaped, with a high relative abundance of small sizes. Curved shaped spectra, with a higher relative abundance of larger sizes, are found during confinement conditions, when there is a lack of nutrient inputs and competitive interactions are expected to be stronger. Finally, stepped shapes with more than one mode appear whenever an increase of biomass takes place in a particular size range and are attributable to a variation in the population dynamics of the species involved. This subscale makes up the tertiary or population scaling, according to Dickie et al. (1987).

These patterns in spectra scaling are also easily identifiable in the size distributions in the Espolla pond. Most of its Pareto size distributions show biomass distributed in two groups, which make up the secondary scaling on the biomass spectrum: microcrustaceans (cladocerans, copepods, and ostracods) and macrofauna (turbellarians, oligochaetes, macrocrustaceans,

23 Jan 97

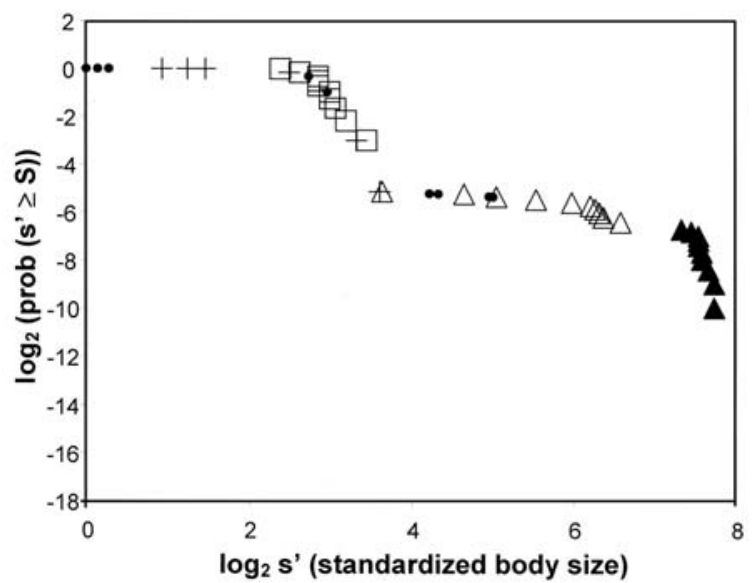

insects, gastropods, and amphibians). The intergroup minimum or swerve point of these cumulative distributions corresponds in all cases to an overlap zone of larger microcrustaceans (ostracods) and smaller macrofauna (turbellarians). In some cases, the tertiary scaling is also observable, especially at the beginning of the hydroperiod, when the initial hatching of the pioneering species takes place. In these circumstances the populations are composed of individuals of similar size, with population sizes well differentiated by species (Fig. 6). This tertiary scale has been related to a fractal nature of the biomass-size spectrum (Margalef, 1991). At the same time, the posterior disappearance of this tertiary scale could be interpreted as a selforganizing behaviour of biomass-size spectrum (Camacho \& Solé, 2001). Thus, both of the theoretical biomass-size spectrum structure characteristics, the fractal, and the self-organizing, may be identified in tertiary scaling of size distribution along succession.
04 Mar 97

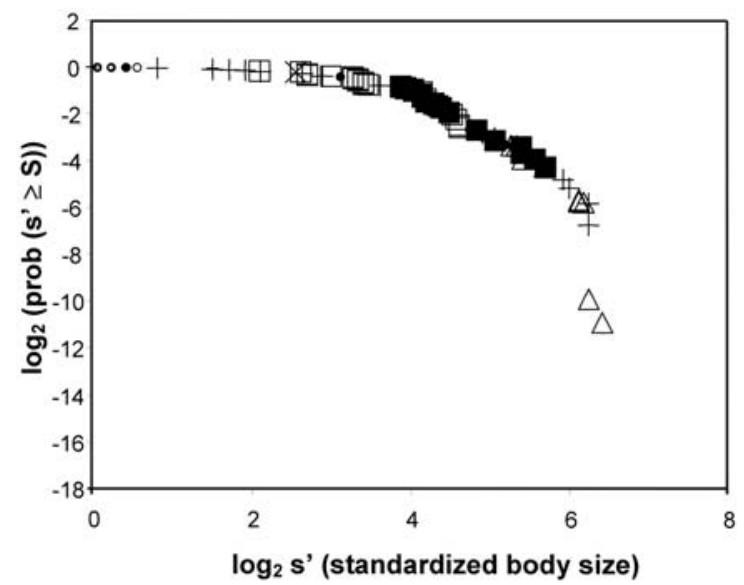

\begin{tabular}{|c|c|c|c|}
\hline$\Delta$ Heterocypris incongruens & $\boldsymbol{\Delta}$ Eucypris virens & $\square$ Megacyclops viridis & Cyclops sp. \\
\hline + Daphnia pulicaria & - Simocephalus vetulus & $\times$ Moina brachiata & o Alona elegans \\
\hline
\end{tabular}

Figure 6. Heleoplankton size distribution on two sampling days, showing the species composition in the Espolla pond. On the first example (23 Jan 97) a tertiary-scale structure appears due to a lack of size overlap among species, which disappear in the second example (04 May 97). Body size has been standardized dividing each value by the minimum size value found. Distribución de tamaños del heleoplancton en dos días de muestreo, mostrando la composición de especies en la laguna de Espolla. En el primer ejemplo (23 enero 97) se observa una estructura de escala terciaria debida a la falta de solapamiento en los tamaños de las diferentes especies, que desaparece en el segundo ejemplo (04 mayo 97). El tamaño corporal se ha estandarizado dividiendo su valor por el mínimo valor de tamaño encontrado. 


\section{COMBINATION OF SIZE-BASED AND TAXON-BASED APPROACHES}

An approximation based on organism size is complementary to a taxonomic approach, not redundant (Strayer 1991; Rodríguez \& Magnan 1993). Thus, the combination of taxon-based and size-based approaches in the study of community structure leads to a better understanding of the ecological functioning of aquatic ecosystems. A comparison of the zooplankton community structure in permanent and temporary water bodies of the Empordà salt marshes, show that they do not differ in their most abundant species, but they do differ in their temporal patterns and size structure (Brucet et al., 2005b). These differences are a consequence of the ecological interactions of the species involved, such as competence and predation, where size acquires great relevance.

The combination of size-based and taxon-based approaches is especially suitable in the study of phytoplankton communities because of the different techniques currently used, such as observation by inverted microscope, identification of pigment contents by HPLC, or particle counting by flow cytometry, some of them more suitable for species (or functional groups) determination, others more suitable for counting. Studies on phytoplankton composition in the Empordà salt marshes show that dinoflagellates (and other potentially phagotrophic organisms such as haptophytes) play an important role in these ecosystems, dominating when nutrients are mainly found in organic form. Furthermore, phytoplankton biomass-size distributions frequently show a lack of intermediate sizes (2.5 - $4 \mu \mathrm{m}$ Equivalent Spherical Diameter), and its magnitude correlates with dinoflagellate biomass (Fig. 7). These results suggest that dinoflagellates take advantage of their mixotrophy by competing with, and grazing on, smaller phytoplankters simultaneously (LópezFlores et al., in press 1). Taxon-based approaches reveal that dinoflagellate species composition and dynamics of these coastal marshes differ from that observed in adjacent open coastal waters (López-Flores et al., in press 2).

The study of the successional patterns found in the invertebrate community of the Espolla pond is another example of the complementarity of size-based and taxon-based approaches. Boix et al. (2004) describe a 3-phase model of faunal succession in the Espolla pond by means of a taxon-based approach, which agrees with succession models described in several previous works for temporary ponds around the world (Kenk 1949; Barclay 1966; Lake et al., 1989; Bazzanti et al., 1996). The first and the last phases correspond to two allogenic succession processes. Flooding involves an available aquatic space with a trophic resource, low competition and low predation, while the disappearance of the flooded surface during drying periods involves changes in the environmental parameters (e.g. higher temperature values and oxygen fluctuations) and in the animal community (higher density values leading to higher competition
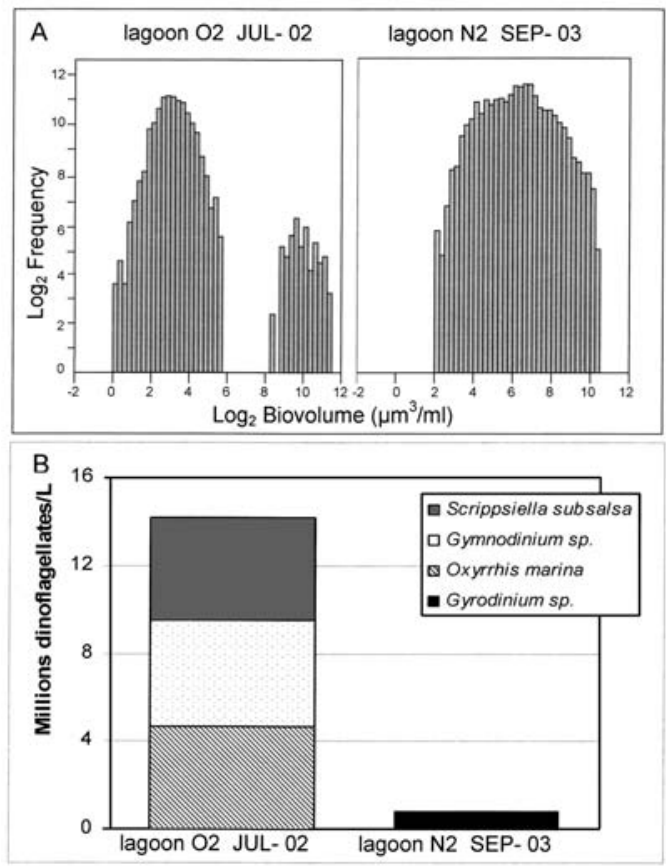

Figure 7. (A) Two kinds of phytoplankton biomass size distributions (sizes between 0 and $10 \mu \mathrm{m}$ ) in two lagoons of la Pletera salt marshes (Baix Ter wetlands). One gapped (left) and one unimodal distribution (right). (B) Abundances of the different dinoflagellate species present in the same samples, modified from LópezFlores et al. (In press, 1). (A) Dos tipos de distribuciones de biomasa (tamaños entre 0 y $10 \mu \mathrm{m}$ ) en dos lagunas de las marismas de la Pletera ("Aiguamolls del Baix Ter"). Una distribución discontinua (izquierda) y una unimodal (derecha). (B) Abundancias de las diferentes especies de dinoflagelados presentes en las mismas muestras, modificado de López-Flores et al. (en prensa, 1). 
and predation). Contrarily, the succession process observed between these two phases is autogenic. The size-based approach distinguishes five phases, which could be related to the three phases of the taxon-based approach, with the intermediate autogenic phase being divided into three additional phases, based on distinct community size structures, which appear throughout the autogenic succession. Observed changes in the middle phase are therefore more related to the size-based structure than to taxa abundance.

\section{Size diversity and species diversity}

One of the main difficulties in the study of biomass-size spectra is the fact that the ecological meaning of the parameters of the size distribution models is normally difficult to interpret. The meaning of a change in the fit to a given model or a change in the slope is not trivial, and great effort is necessary to understand its ecological relevance. This is especially true when size distributions are adjusted to non-linear models, where several parameters are involved. The use of size diversity, that is the computation of a Shannon-Wiener index classifying individuals by their size instead of by their taxon, may solve these difficulties. A size diversity measure gives a unique value per size distribution and has the advantage of a more intuitive interpretation, since the concept of diversity and its ecological meaning is well established. However, a methodological problem emerges when measuring size diversity by clustering the different body sizes in size classes, because the division of a continuum variable (size) into an arbitrarily selected number of size classes is needed. As a result, different size diversity values for the same community were obtained depending on the number of size class intervals chosen (Ruiz, 1994). In order to overcome these problems, Lurie \& Wagensberg (1984) proposed a measure of size diversity index appropriate for continuous variables $(\mu)$, based on the function of probability density of individuals with respect to size, where the summatory of the Shannon function is substituted by the integral of a continuous function of probability density $\mathrm{p}_{i}(\mathrm{~s})$,

$$
\mu=-\int p_{i}(s) \lg _{2} p_{i}(s) \mathrm{d} s
$$

We have used this type of function and the results obtained are compared with those of the Shannon-Wiener index of species diversity (Brucet et al., 2006).

Species diversity and size diversity give complementary information about zooplankton community structure. Relationships found between both diversities and several environmental variables (Table 3) suggest that the size diversity is mainly related to trophic interactions, such as fish predation when fish densities are high, or inter/intraspecific competition for food availability when fish are absent. On the other hand, species diversity appears to be more sensitive to abiotic factors such as trophic state. Differences among size and species diversity values are

Table 3. Pearson correlations between Shannon-Wiener diversity $(H)$, size diversity $\left(\mu_{s}\right)$ and environmental variables related to the trophic state (ammonium, soluble reactive phosphorus, total nitrogen, total phosphorus and total organic carbon), and variables related to species trophic interactions (fish density and food resource availability) of la Pletera (Baix Empordà wetlands). All these variables have previously been $\log _{10}(x+1)$ except both diversity indexes. Significant correlation coefficients and non-significant relationships are indicated $(* p<0.05, * * p<0.01$, n.s. $p>0.05)$. Food resource availability was determined as a quotient between the [bacterial + phytoplankton] biovolume (in $\mu^{3}$ ) and the zooplankton biomass (in $\mu \mathrm{g}$ dry weight). Correlaciones de Pearson entre la diversidad de Shannon-Wiener $(H)$, la diversidad de tamaños $\left(\mu_{s}\right.$, , y variables ambientales relacionadas con el estado trófico (amonio, fósforo reactivo soluble, nitrógeno total, fósforo total y carbono orgánico total) y variables relacionadas con las interacciones tróficas (densidad de peces y disponibilidad de recurso) de la Pletera ("Aiguamolls del Baix Empordà"). Se indican los coeficientes de correlación significativos así como las relaciones no significativas $(* p<0.05, * * p<0.01$, n.s. $p>0.05)$. La variable disponibilidad de recurso se ha obtenido a partir del cociente entre biovolumen de [bacterio- + fitoplancton] (en $\left.\mu^{3}\right)^{3}$ y la biomasa de zooplancton (en $\mu \mathrm{g}$ de peso seco).

\begin{tabular}{lll}
\hline & \multicolumn{1}{c}{$\boldsymbol{H}$} & \multicolumn{1}{c}{$\boldsymbol{\mu}_{\mathbf{s}}}$, \\
\hline Ammonium $\left(\mathrm{mg} \mathrm{N} \cdot \mathrm{1}^{-1}\right)$ & $-0.299^{*}$ & $\mathrm{n} . \mathrm{s}$. \\
Soluble reactive phosphate $\left(\mathrm{mg} \mathrm{P}^{-1} \mathrm{l}^{-1}\right)$ & $-0.414^{* *}$ & n.s. \\
Total nitrogen $\left(\mathrm{mg} \mathrm{N} \cdot \mathrm{l}^{-1}\right)$ & $-0.395^{* *}$ & n.s. \\
Total phosphorus $\left(\mathrm{mg} \mathrm{P} \cdot \mathrm{l}^{-1}\right)$ & $-0.353^{* *}$ & n.s. \\
Total organic carbon $\left(\mathrm{mg} \cdot \mathrm{l}^{-1}\right)$ & $-0.402^{* *}$ & n.s. \\
Fish density (ind $\left.\cdot \mathrm{m}^{-2}\right)$ & & \\
Low fish density lagoons & n.s. & n.s. \\
High fish density lagoons & n.s. & $-0.986^{* *}$ \\
Food resource availability & $0.314^{*}$ & $-0.427^{* *}$ \\
\hline
\end{tabular}



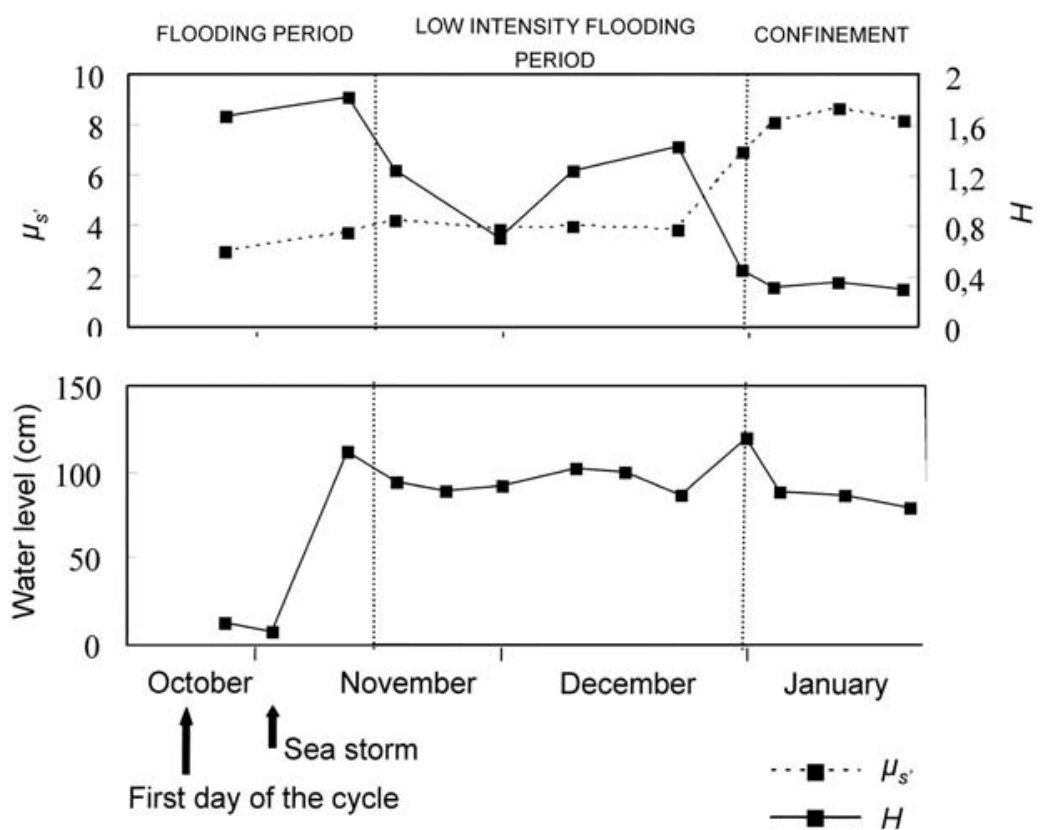

Figure 8. (A) Example of the evolution of size diversity $\left(\mu_{s^{\prime}}\right)$ and species diversity $(H)$ in a temporary lagoon. (B) Evolution of water level for the same cycle. Discontinuous lines separate three periods: the first correspond to a period of intense disturbances (arrows indicate flooding events with more than $100 \%$ in water level increase); the second is a flooding period with low and irregular water inputs (water level increase always less than $40 \%$ ), and the third is a confinement period without water inputs, which causes a progressive decrease in water level. Modified from Brucet et al. (2006). (A) Ejemplo de la evolución de la diversidad de tamaños $\left(\mu_{\mathrm{s}}\right)$ y la diversidad de especies $(\mathrm{H})$ en una laguna temporal. (B) Evolución del nivel del agua durante el mismo ciclo. Las líneas discontinuas separan tres periodos: el primero corresponde a un periodo de perturbaciones intensas (las flechas indican inundaciones en las que el incremento del agua es mayor al $100 \%$ ), el segundo es un periodo de entradas de agua irregulares y de baja intensidad (incremento del agua siempre menor al $40 \%$ ), y el tercero es un periodo de confinamiento sin entrada de agua, que causa una disminución progresiva del nivel del agua. Modificado de Brucet et al. (2006).

especially notable when they are compared along the succession gradient in fishless basins (Fig. 8). Species diversity increases after flooding, but decreases along the succession, when exploitative competition leads to the dominance of only one calanoid species. This agrees with the postulates of Connell's (1978) intermediate disturbance hypothesis. Besides, size diversity increases along the succession and the highest size diversity values coincide with the above-mentioned dominance of calanoids (Brucet et al., 2006).

Comparing the behaviour of both diversity indexes lead to the conclusion that the combined use of size and species diversity may give a better understanding of ecological processes ruling the community structure. A wider interpretation of the concept of diversity, beyond the classical interpretation limited to species diversity was proposed earlier by Margalef (1980 and 1991), as discussed in Rodríguez (2005). Margalef pointed out the importance of size and turnover in diversity spectra and their relationship with some ecological aspects, such as those related to the transference of energy. Thus, all our work is only a small part of Margalef's heritage, being simply the development of Margalef previously proposed concepts.

\section{REFERENCES}

ALONSO, M. 1998. Las lagunas de la España peninsular. Limnetica, 15: 1-176.

ÁlVAREZ-COBELAS, M., C. ROJO \& D. G. ANGELER. 2005. Mediterranean limnology: current status, gaps and the future. Journal of Limnology, 64(1):13-29.

BADOSA, A., D. BOIX, S. BRUCET, R. LÓPEZFLORES \& X. D. QUINTANA. 2006. Nutrients 
and zooplankton composition and dynamics in relation to the hydrological pattern in a confined Mediterranean salt marsh (NE Iberian Peninsula). Estuarine Coastal and Shelf Science, 66: 513-622.

BARCLAY, M. H. 1966. An ecological study of a temporary pond near Auckland, New Zealand. Australian Journal of Marine and Freshwater Research, 17: 239-258.

BAZZANTI, M., S. BALDONI \& M. SEMINARA. 1996. Invertebrate macrofauna of a temporary pond in central Italy: composition, community parameters and temporal succession. Archiv für Hydrobiologie, 137: 77-94.

BEKLIOGLU, M., Ö. INCE \& I. TÜZÜN. 2003. Restoration of Eutrophic Lake Eymir, Turkey, by Biomanipulation Undertaken Following a Major External Nutrient Control I. Hydrobiologia, 489: 93-105.

BOIX, D., J. SALA \& R. MORENO-AMICH. 2001a. Succession of the macroinvertebrate community in a temporary pond. Ver. Internat. Verein. Limnol., 27: 2586-2593.

BOIX, D., J. SALA \& R. MORENO-AMICH. 2001b. The faunal composition of Empolla pond (NE Iberian Peninsula): the neglected biodiversity of temporary waters. Wetlands, 21(4): 577-592.

BOIX, D. \& J. SALA. 2002. Riqueza y rareza de los insectos acuáticos de la laguna temporal de Espolla (Pla de l'Estany, Cataluña). Boletín de la Asociación Española de Entomología, 26 (1-2): 45-57.

BOIX, D., J. SALA \& R. MORENO-AMICH. 2002. Population dynamics of Triops cancriformis (Crustacea: Branchiopoda: Notostraca) of the Espolla temporary pond in the northeastern Iberian peninsula. Hydrobiologia, 486: 175-183.

BOIX, D., J. SALA, X. D. QUINTANA \& R. MORENO-AMICH. 2004. Succession of the animal community in a Mediterranean temporary pond. J. North Am. Benthol. Soc., 23: 29-49.

BOIX, D., S. GASCÓN, J. SALA, M. MARTINOY, J. GIFRE \& X. D. QUINTANA. 2005. A new index of water quality assessment in Mediterranean wetlands based on crustacean and insect assemblages: the case of Catalunya (NE Iberian peninsula). Aquatic Conservation: Marine and Freshwater Ecosystems, 15: 635-651.

BONGERS, T. 1990. The Maturity Index: an ecological measure of environmental disturbance based on nematode composition. Oecologia, 83:14-19.

BORONAT, L., R. MIRACLE \& X. ARMENGOL. 2001. Cladoceran assemblages in a mineralization gradient. Hydrobiologia, 442: 75-88.
BRITTON, R. H. \& V. D. PODLEJSKI. 1981. Inventory and classification of the wetlands of the Camargue (France). Aquatic Botany, 10: 195-228.

BRITTON, R. H. \& A. J. CRIVELLI. 1993. Wetlands of southern Europe and North Africa: Mediterranean wetlands. In: Wetlands of the world I: Inventory, ecology and management. Whigham, D. F., D. Dykyjová \& S. Hejn (eds.): 129-194. Kluwer Academic Publishers, Dordrecht.

BRUCET, S., D. BOIX, R. LÓPEZ-FLORES, A. BADOSA \& X. D. QUINTANA. 2005a. Ontogenic changes of amino acid composition in crustacean species. Marine Biology, 148: 131139.

BRUCET, S., D. BOIX, R. LÓPEZ-FLORES, A. BADOSA, R. MORENO-AMICH \& X. D. QUINTANA. 2005b. Zooplankton structure and dynamics in permanent and temporary Mediterranean salt marshes: taxon-based and size-based approaches. Archiv für Hydrobiologie, 162: 535-555.

BRUCET, S., X. D. QUINTANA, R. MORENOAMICH \& D. BOIX. 2005c. Changes in the shape of aquatic invertebrates' biomass-size spectra at ecological scaling in a fluctuant ecosystem (Empordà wetlands, NE Spain). Vie et Milieu, 55: 31-40.

BRUCET, S., D. BOIX, R. LÓPEZ-FLORES, A. BADOSA, R. MORENO-AMICH \& X. D. QUINTANA. 2006. Size diversity and species diversity of zooplankton communities in fluctuant Mediterranean salt marshes. Estuarine Coastal and Shelf Science, 67: 424-432.

CAMACHO, J. \& R. V. SOLÉ. 2001. Scaling in ecological size spectra. Europhysics Letters, 55: 774780 .

COMÍN, F. A. \& I. VALIELA. 1993. On the controls of phytoplankton abundance and production in coastal lagoons. Journal of Coastal Research, 9: 895-906.

CONNELL, J. H. 1978. Diversity in tropical rain forest and coral reefs. Science, 199: 1302-1310.

DICKIE, L. M., S. R. KERR \& P. R. BOUDREAU. 1987. Size-dependent processes underlying regularities in ecosystem structure. Ecological Monographs, 57(3): 233-250.

FERNÁNDEZ-ALÁEZ， C., M. FERNÁNDEZALÁEZ \& E. BÉCARES. 1999. Influence of water level fluctuations on the structure and composition of the macrophyte vegetation in two small temporary lakes in the northwest of Spain. Hydrobiologia, 415: 155-162.

FERNÁNDEZ-ALÁEZ, M., C. FERNÁNDEZALÁEZ, E. BÉCARES, M. VALENTÍN, J. 
GOMA \& P. CASTRILLO. 2004. A two-year experimental study on nutrient and predator influences on food web constituents in a shallow lake of north-west Spain. Freshwat. Biol., 49: 1574-1592.

FERNÁNDEZ-DELGADO, C., J. A. HERNANDOCASAL, M. HERRERA \& M. BELLIDO. 1988. Age, growth and reproduction of Aphanius iberus (Cu. \& Val., 1846) in the lower reaches of the Guadalquivir river (south-west Spain). Freshwat. Biol., 20: 227-234.

FERNÁNDEZ, F. 1979. Nutrition studies in nauplius larva of Calanus pacificus (Copepdoda: Calanoida). Marine Biology, 53:131-147.

FRASCARI, F., G. MATTEUCCI \& P. GIORDANO. 2002. Evaluation of a eutrophic coastal lagoon ecosystem from the study of bottom sediments. Hydrobiologia, 475/476: 387-401.

GAEDKE, U. 1992. The size distribution of plankton biomass in a large lake and its seasonal variability. Limnol. Oceanogr., 37(6): 1202-1220

GASCÓN, S., D. BOIX, J. SALA \& X. D. QUINTANA. 2005. Variability of benthic assemblages in relation to the hydrological pattern in Mediterranean salt marshes (Empordà wetlands, NE Iberian Peninsula). Archiv für Hydrobiologie, 163: 163-181.

GASCÓN, S., D. BOIX, J. SALA \& X. D. QUINTANA. (In press 1). Nematode assemblages and their response to disturbances: a case study from the Empordà wetlands (NE Iberian Peninsula). $J$. North Am. Benthol. Soc., (In press)

GASCÓN, S., D. BOIX, J. SALA \& X. D. QUINTANA. (In press 2). Effects of a drying crisis on the macrobenthic fauna of a Mediterranean salt marsh (Empordà Wetlands, NE Iberian Peninsula), with special emphasis on the Corophium orientale population. Vie et Milieu.

GESTI, J., A. BADOSA \& X. D. QUINTANA. 2005. Reproductive potential in Ruppia cirrhosa (Petagna) Grande in response to water permanence. Aquatic Botany, 81: 191-198.

GIFRE, J., X. D. QUINTANA, R. BARRERA, M. MARTINOY \& E. MARQUÈS. 2002. Ecological factors afecting ostracod distribution in lentic ecosystems of Empordà wetlands (NE Spain). Archiv für Hydrobiologie, 154: 499-514.

GILABERT, J. 2001. Short-term variability of the planktonic size structure in a Mediterranean coastal lagoon. Journal of Plankton Research, 23(2): 219-226.

GUISANDE, C., F. BARTUMEUS, M. VENTURA \& J. CATALAN. 2003. Role of food partitioning in structuring the zooplankton community in mountain lakes. Oecologia, 136: 627-634.

HAN, B. P. \& M. STRASKRABA. 1998. Size dependence of biomass spectra and population density I. The effects of size scales and size intervals. Journal of Theoretical Biology, 191: 259-265.

HEURTEAUX, P. 1992. Modifications du regime hydrique et salin des étangs du système de Vaccarès (Camargue, France) liées aux perturbations anthropiques des cinquante dernières années. Annales de Limnologie, 28 : 157-174.

KENK, R. 1949. The animal life of temporary and permanent ponds in southern Michigan. Miscellaneous Publications, Museum of Zoology, University of Michigan, 71:1-66.

KERR, S. R. \& L. M. DICKIE. 2001. The biomass spectrum. A predator-prey theory of aquatic production. Columbia University Press, New York. 320 pp.

LAKE, P. S., I. A. E. BAYLY \& D. W. MORTON. 1989. The phenology of a temporary pond in western Victoria, Australia, with special reference to invertebrate succession. Archiv für Hydrobiologie, 115:171-202.

LÓPEZ-FLORES, R., X. D. QUINTANA, V. SALVADÓ, M. HIDALGO, L. SALA \& R. MORENO-AMICH. 2003. Comparison of nutrient and contaminant fluxes in two areas with different hydrological regimes (Empordà Wetlands, NE Spain). Water Research, 37: 3034-3046.

LÓPEZ-FLORES, R., D. BOIX, A.BADOSA, S. BRUCET \& X. D. QUINTANA. (In press 1). Phytoplankton composition and size distribution in a confined Mediterranean salt marsh ecosystem. Marine Biology.

LURIE, D. \& J. WAGENSBERG. 1984. An extremal principle for biomass diversity in ecology. In: Thermodinamics and regulation of biological processes. I. LAMPRECHT \& A. I. ZOTIN (eds.): 257-271. Walter de Gruyter and Co, Berlin.

MARGALEF, R. 1980. La biosfera: entre la termodinámica y el juego. Editorial Omega. Barcelona. $236 \mathrm{pp}$.

MARGALEF, R. 1991. Teoría de los sistemas ecológicos. Publicacions de la Universitat de Barcelona, Barcelona. 290 pp.

MARTINOY, M., D. BOIX, J. SALA, S. GASCÓN, J. GIFRE, A. ARGERICH, R. BARRERA, S. BRUCET, A. BADOSA, R. LÓPEZ-FLORES, M. MÉNDEZ, J. M. UTGÉ \& X. D. QUINTANA. 2006. Crustacean and aquatic insect assemblages in the Mediterranean coastal ecosystems of Empordà Wetlands (NE Iberian Peninsula). Limnetica, 26 (3-4). 
OLTRA, R. \& R. TODOLÍ. 2000. Reproduction of the endangered killifish Aphanius iberus at different salinities. Environmental Biology of Fishes, 57: 113-115.

PAFFENHÖFER, G. A. 1971. Grazing and ingestion rates of nauplii, copepodids and adults of the marine planktonic copepod Calanus helgolandicus. Marine Biology, 11: 286-298

PÉREZ-RUZAFA, A., J. GILABERT, J. M. GUTIÉRREZ, A. I. FERNÁNDEZ, C. MARCOS \& S. SABAH. 2002. Evidence of a planktonic food web response to changes in nutrient input dynamics in the Mar Menor coastal lagoon, Spain. Hydrobiologia, 475/476: 359-369.

PLATT, T. \& K. DENMAN. 1977. Organisation in the pelagic ecosystem. Helgoländer Wissenschaftliche Meeresuntersuchungen, 30: 575-581.

POULET S. A. 1977. Grazing of marine copepod developmental stages on naturally occurring particles. J.Fish. Res.Board Canada, 34: 2381-2387

QUINTANA, X. D. 2002a. Measuring the intensity of disturbance in zooplankton communities of Mediterranean salt marshes using multivariate analysis. J. Plankton Res., 24: 255-265.

QUINTANA, X. D. 2002b. Estimation of water circulation in a Mediterranean salt marsh and its relationship with flooding causes. Limnetica, 21: 25-35.

QUINTANA, X. D., R. MORENO-AMICH \& F. A. COMÍN. 1998a. Nutrient and plankton dynamics in a Mediterranean salt marsh dominated by incidents of flooding. Part.1: Differential confinement of nutrients. J. Plankton Res., 20: 2089-2107.

QUINTANA, X. D., F. A. COMÍN \& R. MORENOAMICH. 1998b. Nutrient and plankton dynamics in a Mediterranean salt marsh dominated by incidents of flooding. Part.2: Response of the zooplankton community to disturbances. J.Plankton Res., 20: 2109-2127.

QUINTANA, X. D., F. A. COMÍN \& R. MORENOAMICH. 2002. Biomass-size spectra in aquatic communities in shallow fluctuating Mediterranean salt marshes (Empordà wetlands, NE Spain). J. Plankton Res., 24: 1149-1161.

QUINTANA, X. D., D. BOIX, A. BADOSA, S. BRUCET, S. GASCÓN, J. GESTI, R. LÓPEZFLORES, Q. POU-ROVIRA, R. TROBAJO \& R. MORENO-AMICH. 2004. Limnología de los humedales costeros mediterráneos. El caso de Aiguamolls de l'Empordà. Ecosistemas, 2004/2.

RODRÍGUEZ, J. 1994. Some comments on the sizebased structural analysis of the pelagic ecosystem. Scientia Marina, 58: 1-10.
RODRÍGUEZ, J. 2005. La estructura de tamaños del plankton: un tópico interdisciplinary $\mathrm{y}$ Margalefiano. Ecosistemas, 2005/1.

RODRIGUEZ, J. \& M. M. MULLIN. 1986. Relation between biomass and body weight of plankton in a steady state oceanic ecosystem. Limnol. Oceanogr., 31(2): 361-370.

RODRÍGUEZ, M. A. \& P. MAGNAN. 1993. Community structure of lacustrine macrobenthos: Do taxon-based and size-based approaches yield similar insights? Can. J. Fish. Aquat. Sci., 50: 800-815.

ROMO S., M. R. MIRACLE, M. J. VILLENA, J. RUEDA, C. FERRIOL \& E. VICENTE. 2004. Mesocosm experiments on nutrient and fish effects on shallow lake food webs in a Mediterranean climate. Freshwat. Biol., 49: 1593-1607.

ROMO, S., M. J. VILLENA, M. SAHUQUILLO, J. M. SORIA, M. GIMENEZ, T. ALFONSO, E. VICENTE \& M. R. MIRACLE. 2005. Response of a shallow Mediterranean lake to nutrient diversion: does it follow similar patterns as in northern shallow lakes? Freshwat. Biol., 50 (10): 17061717.

RUIZ, J. 1994. The measurement of size diversity in the pelagic ecosystem. Scientia Marina, 58: 103107.

SALA, J., S. GASCÓN, D. BOIX, J. GESTI \& X. D. QUINTANA. 2004. Proposal of a rapid methodology to assess the conservation status of Mediterranean wetlands and its application in Catalunya (NE Iberian peninsula). Archives des Sciences, 57: 143-154.

SALVADÓ, V., X. D. QUINTANA \& M. HIDALGO. 2006. Monitoring of nutrients, pesticides and metals in waters, sediments and fish of a wetland. Archives of Environmental Contamination and Toxicology. (in press).

STRAYER, D. L. 1991. Perspectives on the size structure of lacustrine zoobenthos, its causes and its consequences. J. North Am. Benthol. Soc., 10: 210-221.

TROBAJO, R., X. D. QUINTANA \& S. SABATER. 2004a. Factors affecting the periphytic diatom community in Mediterranean coastal wetlands (Empordà wetlands, NE Spain). Archiv für Hydrobiologie, 160(3): 375-399.

TROBAJO, R., E. J. COX \& X. D. QUINTANA. 2004b. The effects of some environmental variables on the morphology of Nitzschia frustulum (Bacillariophyta), in relation its use as a bioindicador. Nova Hedwigia, 79: 433-445.

TROBAJO, R., X. D. QUINTANA \& R. MORENOAMICH. 2002. Model of alternative predominance of 
phytoplankton-periphyton-macrophytes in relation to nutrient level in lentic systems in Mediterranean coastal wetlands. Archiv für Hydrobiologie, 154: 19-40.

VARGAS, M. J. \& A. de SOSTOA. 1997. Life-history pattern of the Iberian toothcarp Aphanius iberus (Pisces, Cyprinodontidae) from a Mediterranean estuary, the Ebro delta (Spain). Netherlands Journal of Zoology, 47:143-160.

VIDONDO, B., Y. T. PRAIRIE, J. M. BLANCO \& C. M. DUARTE. 1997. Some aspects of the analysis of size spectra in aquatic ecology. Limnol. Oceanogr., 42: 184-192.
VILLENA, M. J. \& S. ROMO. 2003. Phytoplankton changes in a shallow Mediterranean lake (Albufera of Valencia, Spain) alter sewage diversion. Hydrobiologia, 506-509: 281-287.

WELLBORN, G. A., D. K. SKELLY \& E. E. WERNER. 1996. Mechanisms creating community structure across a freshwater habitat gradient. Annual Review of Ecology and Systematics, 27: 337-363.

WERNER, E. E. \& J. F. GILLIAM. 1984. The ontogenetic niche and species interactions in sizestructured populations. Annual Review of Ecology and Systematics, 15, 393-425. 